\title{
SLEEP OF THE SOUL AND RESURRECTION OF THE BODY: APHRAHAT'S ANTHROPOLOGY IN CONTEXT
}

\author{
J. EDWARD WALTERS
}

ROCHESTER UNIVERSITY

\begin{abstract}
The fourth-century Syriac corpus known as the Demonstrations, attributed to Aphrahat, the Persian Sage, provides a unique window into the early development of Christianity among Syriac-speaking communities. Occasionally these writings attest to beliefs and practices that were not common among other contemporaneous Christian communities, such as Aphrabat's apparent belief in the "sleep of the soul" and the implications of that belief for his concept of the soul-body relationship and what happens to the soul and body at the resurrection. Aphrahat addresses this topic in the context of a polemical argument against an unnamed opponent, which provides the occasion to consider whom these arguments might be addressed against. The present article seeks to understand Aphrahat's views on the body and soul within the broad religious milieu of the eastern Mediterranean world in Late Antiquity. The article concludes with an argument for reading and understanding the Demonstrations as a witness to the contested development of Christian identity in the Syriac-speaking world.
\end{abstract}




\section{INTRODUCTION}

Aphrahat, the so-called Persian Sage, ${ }^{1}$ is a relatively obscure figure in the history of early Christianity despite the intriguing historical context of his life and writings. ${ }^{2}$ According to colophons found within the Demonstrations, it can be reasonably assumed that he lived somewhere within the Persian Empire 3 during the early years of the

1 The name "Aphrahat" does not come to be associated with the "Persian Sage" mentioned as the author of the Demonstrations until relatively late $\left(8^{\text {th }}\right.$ century). Previously, the Persian Sage was either unnamed (BL Add. 14,619; BL Add. 17,182 [part 1]; letters of George, bishop of the Arabs) or called Jacob (BL Add. 17,182 [part 2]). But later tradition accepts the name Aphrahat as the correct identification of the Persian Sage (Barbahlul, Gregory Bar 'Ebroyo, 'Abdisho).

2 Aphrahat's writings survive in the form of twenty-three rdïnow, which is generally translated "Demonstrations." Two versions of the Syriac text have been published: William Wright, ed., The Homilies of Aphraates, the Persian Sage, edited from Syriac Manuscripts of the fifth and sixth Century in the British Museum, Vol. 1: The Syriac Text (London: Williams and Norgate, 1869) [note: this was intended as a two volume set with an English translation in the second volume, but the second volume was never completed]; and D. Ioannes Parisot, ed., Aphraatis Sapientis Persae Demonstrationes I-XXII (Patrologia Syriaca 1.1; Paris: Firmin-Didot, 1894), and D. Ioannes Parisot, ed., Aphraatis Sapientis Persae Demonstrationes XXIII (Patrologia Syriaca 1.2; Paris: Firmin-Didot, 1907), columns 1-150. In recent years, modern translations of the Demonstrations into French, German, English, and Italian have appeared: Marie-Joseph Pierre, Aphraate le Sage Persan. Les Exposés. SC 349, 359 (Paris: Les Éditions du Cerf, 1988, 1989); Peter Bruns, Aphrahat. Unterweisungen (FC 5.1-2; Freiburg: Herder, 1991-1992); Kuriakose Valavanolickal, Aphrahat. Demonstrations. Mōrān 'Eth'ō 23-24 (Kottayam: St. Ephrem Ecumenical Research Institute, 2005); Adam Lehto, The Demonstrations of Aphrahat, the Persian Sage (Gorgias Early Christian Studies 27; Piscataway, NJ: Gorgias Press, 2010); and Giovanni Lenzi, Afraate: Le esposizioni, 2 Vols. (Testi del Vicino Oriente antico; Brescia: Paideia, 2012).

${ }^{3}$ It is not possible to determine Aphrahat's precise location from his writings. Demonstration 14 is addressed to the leaders of the Church in Seleucia-Ctesiphon, but this does not provide any concrete information for the author's locale. The scribe of one late manuscript (14 ${ }^{\text {th }}$ century) in the British Library (BM Orient. 1017) claims that Aphrahat was the bishop of the monastery of Mar Mattai (located in modern-day northern Iraq, near Mosul). However, this claim is suspect and certainly anachronistic; cf. S.P. Brock, "Aphrahat" in Brock, et al, Gorgias Encyclopedic Dictionary of the Syriac Heritage (Piscataway: Gorgias Press, 2011), 24-25. 
reign of Shapur II. ${ }^{4}$ The religious milieu of early fourth-century Persia featured a several-century-old state religion in revival (Zoroastrianism) that was competing not only with well-established religions like Judaism, but also with native folk religions, the influx of Greek philosophical schools, and various expressions of Christianity. ${ }^{5}$ Despite this fascinating context, Aphrahat's writings have received surprisingly little attention as a witness to religious diversity in fourth-century Persia. The little attention scholars have extended to his work in this regard has been focused mainly on his depiction of Judaism. While Judaism does feature prominently in several segments of Aphrahat's Demonstrations, particularly in Demonstrations 11-22, his writings also offer a unique perspective on the state of Christianity in early fourth-century Persia.

The present article seeks to offer an example of Aphrahat's unique expression of ideas and the way his thought fits within the broader religious milieu of early Syriac-speaking Christianity, namely his beliefs about the body/soul relationship and what happens to the body and soul at death and in the resurrection. In his discussions of these topics, Aphrahat demonstrates both continuity and discontinuity with other early Christian and Jewish sources, and his unique perspective is likely the result of the diverse context in which

4 The precise dates of Aphrahat's birth and death are unknown, but dates for the Demonstrations are provided directly within the work: Demonstrations 1-10 were composed in 336-7 CE, Demonstrations 11-22 in 343-4 CE, and Demonstrations 23 was written in 345 CE; see Aphrahat, Demonstrations 14.40 (Parisot, Aphraatis, I.724.24-I.725.2), 22.25 (Parisot, Aphraatis, I.1044.11-20), and 23.69 (Parisot, Aphraatis, II.149.1-10). Although there is no specific reason to doubt the accuracy of the information provided in the colophons, it is important to note that I have argued elsewhere that the Demonstrations is likely not the work of a single author, but rather an edited corpus. See Walters, "Reconsidering the Compositional Unity of Aphrahat's Demonstrations," in Aaron Michael Butts and Robin Darling Young, eds., Syriac Christian Culture: Beginnings to Renaissance (CUA Press, forthcoming).

${ }^{5}$ For a brief, but excellent overview of the Iranian religious milieu in which early Syriac Christianity developed, see Carsten Colpe, "Development of Religious Thought," in Eshan Yarshater, ed., The Cambridge History of Iran, Vol. 3(2): The Seleucid, Parthian, and Sasanian Periods (Cambridge: Cambridge University Press, 1983), 819-865; for more specifically on the early history of Christianity in Iran, see J.P. Asmussen, "Christians in Iran," in idem., 924-948. 
Persian Christianity developed. In particular, Aphrahat's bipartite view of humanity, the idea of the 'sleep of the soul,' and an idiosyncratic depiction of the Holy Spirit's role in conjunction with the body/soul in life, death, and the resurrection provide a test case for examining the complex web of ideas that shape the content of Aphrahat's writings.

Offering first a brief sketch of Aphrahat's views on the body and soul relationship, this article proceeds by comparing Aphrahat's perspective to the literature of various contemporaneous religious communities with which he could have interacted or about whom he may have been aware. The most obvious point of comparison is, of course, Judaism, but this point merits caution. The literary remains of Judaism for this time period are the writings of the Rabbis. Most of these were compiled well after Aphrahat's time of writing, yet some of them reflect much earlier traditions. If Aphrahat was not familiar with proper "Rabbinic" Judaism, as Jacob Neusner has argued, ${ }^{6}$ then we cannot assume that traditions found in Rabbinic writings would be consistent with Aphrahat's depiction of his Jewish interlocutors. Naomi Koltun-Fromm's recent treatment of this problem is quite helpful here because she offers a way of dealing with shared exegetical and hermeneutical traditions between Rabbinic Judaism and Syriac Christianity that resists the urge to draw direct, causal relationships between the texts. ${ }^{7}$ She focuses instead

${ }^{6}$ Early scholarship on this topic argued that Aphrahat's writings showed evidence of rabbinic influence. See for example Salomon Funk, Die haggadischen Elemente in den Homilien des Aphraates, des persischen Weisen (Vienna: Druck von Moritz, 1891); and Frank Gavin, Aphraates and the Jews: A Study of the Controversial Homilies of the Persian Sage in Their Relation to Jewish Thought (New York: AMS Press, 1966). Neusner depicted Aphrahat's writings as reflective of a sort of folk, non-Rabbinic Judaism; see Jacob Neusner, Aphrahat and Judaism: The Christian-Jewish Argument in Fourth-Century Iran (Leiden: Brill, 1971; reprint: Atlanta: Scholars Press, 1999), see particularly pp. 144-149. Most recently, Eliyahu Lizorkin has argued that Aphrahat and his community encountered and interacted with "Rabbinic-related, ParaRabbinic Jews," which seems in large part to overlap with Neusner's argument; E. Lizorkin, Aphrahat's Demonstrations: A Conversation with the Jews of Mesopotamia, CSCO 642 (Leuven: Peeters, 2012), 158.

7 Koltun-Fromm's arguments can be found in a number of publications: "A Jewish-Christian Conversation in Fourth-Century Persian Mesopotamia," Journal of Jewish Studies 47.1 (1996), 45-63, which has been revised, expanded, and re-published as Naomi Koltun-Fromm, Jewish- 
on the way that Aphrahat and the Rabbis each shaped these received hermeneutical traditions in their own contexts. The question of whether Aphrahat's writings on Jews reflect a "real" Jewish opponent or whether they function as a rhetorical device for Aphrahat's intended audience remains a contested issue. ${ }^{8}$

Beyond Judaism, however, there are also less obvious points of comparison with Aphrahat. Indeed, it is quite possible that Aphrahat was also familiar with other expressions of Christianity within the Syriac-speaking milieu, namely followers of Marcion, Bardaisan, and Mani. There is significant evidence (both primary ${ }^{9}$ and secondary ${ }^{10}$ )

Christian Conversation in Fourth-Century Persian Mesopotamia: A Reconstructed Conversation (Judaism in Context 12; Piscataway, NJ: Gorgias Press, 2011), and especially The Hermeneutics of Holiness: Ancient Jewish and Christian Notions of Sexuality and Religious Community (Oxford: University Press, 2010).

${ }^{8}$ For a recent argument that Aphrahat's Jewish opponents represent real interactions with a Jewish community, see Lizorkin, Aphrahat's Demonstrations; for my own argument that Aphrahat employs "imagined Jews" as a rhetorical strategy, see Walters, "Anti-Jewish Rhetoric and Christian Identity in Aphrahat's Demonstrations," in Aaron Michael Butts and Simcha Gross, eds., Judaism and Syriac Christianity: Identities and Intersections (Mohr Siebeck, forthcoming).

${ }^{9}$ While very few original Manichaean writings are preserved in Syriac, Mani himself is traditionally thought to have written in Syriac or at least in an Aramaic dialect (cf. Eusebius HE 4.30.1; Epiphanius Pan. IV.36.1), and several Manichaean works in other languages are presumed to have had Syriac Vorlagen. F.C. Burkitt gathered some of the surviving fragments of Syriac Manichaean literature in The Religion of the Manichees (Cambridge: Cambridge University Press, 1925), 111-118. For a more recent treatment of Manichaeism and Syriac literature, see Erica C.D. Hunter, "Syriac Sources and Manichaeism: A Four Hundred Year Trajectory," in Jacob van den Berg, Annemaré Kotzé, Tobias, Nicklas, and Madeleine Scopello, eds., In Search of Truth: Augustine, Manichaeism and other Gnosticism. Nag Hammadi and Manichaean Studies, 74 (Leiden: Brill, 2010), 291-300.

${ }^{10}$ Ephrem the Syrian explicitly denounces the followers of these three teachers in two surviving polemical works, one a prose text (S. Ephraim's Prose Refutations of Mani, Marcion, and Bardaisan, 2 Vols., transcribed and translated by C. W. Mitchell [London: Williams and Norgate, 1912]), and the other a collection of poetry (Des heiligen Ephraem des Syrers Hymnen contra Haereses ed. and tr. Edmund Beck [CSCO 169-170, Scrip. Syr. 76-77; Louvain: Imprimerie Orientaliste, 1957]). Moreover, Titus of Bostra's Contra Manichaeos was also translated into Syriac quite early (Paul de Lagarde, ed., Titi Bostreni contra manichaeos libri quatuor syriace [London: Williams and 
for the prominence of these movements as alternative expressions of Christianity in the Syriac-speaking world in Aphrahat's time period. Moreover, there is evidence from within Aphrahat's writings that he was aware of such communities. ${ }^{11}$ And although Aphrahat never explicitly directs a polemic against the teachings of these religious groups, there are particular arguments in the Demonstrations against what he calls "deceptive teachings," which seem to suggest a conscious effort to oppose alternative Christian teachings, including Aphrahat's treatment of the resurrection. Thus, it is possible that Aphrahat's intra-Christian arguments are directed against one of these heterodox Christian groups. As a result, the present project seeks to identify points of continuity and discontinuity on the topic of the resurrection and the body/soul relationship between Aphrahat and these contemporaneous religious communities.

\section{SKETCH OF APHRAHAT'S ANTHROPOLOGY}

Although Aphrahat's most extensive treatment of the resurrection appears in Demonstration 8 ("On the Resurrection of the Dead"), he first addressed the topic in Demonstration 6 ("On the Bnay Qyama") within the context of his discussion of Christians receiving the Holy Spirit at baptism. Aphrahat compares the event of baptism with the creation of humanity, and it is here that he offers some insight into his views on the body/soul relationship. The main point of comparison for the two events is the reception of the Holy Spirit at baptism and the moment in the creation narrative when God breathed 'the spirit' into Adam:

Norgate, 1859]), which suggests the popularity of anti-Manichaean texts in the Syriac tradition. In his work on Ephrem's polemical writings, John Reeves argued that Ephrem was "the most important textual witness to the earliest forms of Manichaean discourse," primarily because Ephrem preserved, in Syriac, what are sure to be citations from Mani's followers and Manichaean literature. See John C. Reeves, "Manichaean Citations from the Prose Refutations of Ephrem," in Emerging from Darkness: Studies in the Recovery of Manichaean Sources, ed. Paul Mirecki and Jason BeDuhn (Nag Hammadi and Manichaean Studies 43; Leiden: Brill, 1997), 217-288.

${ }^{11}$ Aphrahat, seemingly in passing, mentions teachings and practices associated with Marcion, Valentinus (perhaps thought of as the 'source' for Bardaisan), and Mani in Dem. 3.9 (Parisot, Aphraatis, I.116.4-17). This passage is discussed in further detail below. 


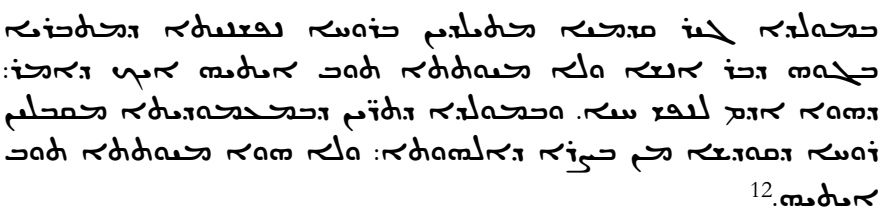

For in the first birth, [humans] are born with a rwoi rowras, which is created within a person and it is not subject to death, as [Scripture] says: 'The man became a living soul.' And in the second birth - that is, in baptism[the baptized] receive the Holy Spirit from a portion of the divinity, which is also not subject to death. ${ }^{13}$

In this brief statement, Aphrahat compares the animation of Adam's body, via God's breath (Gen. 2:7), with the Christian's reception of the Holy Spirit in baptism. ${ }^{14}$ Although he does not state it explicitly, the logical conclusion of his citation of Gen 2:7 in reference to the creation of the roweas ruar is that the breath of God actually became the rowras ruai of humanity. 15

The link between God's breath and the roweas rwai is forged, at least in part, on linguistic principles. Although the Hebrew text of Gen 2:7 uses נשמה for 'breath,' and the Syriac Peshittta follows the Hebrew by using rash, Aphrahat's allusions to Gen 2:7 always employ ruai for the breath of God. ${ }^{16}$ It is not clear if Aphrahat used ruar here because he inherited it as part of the translation of Gen $2: 7$, though it is clear that he is not relying upon the Targum

${ }^{12}$ Dem. 6.14 (Parisot, Aphraatis, I.293.5-11).

${ }^{13}$ All translations from Aphrahat are my own, unless otherwise noted.

${ }^{14}$ The creation imagery is made even more explicit in the broader context of the argument about baptism: "at the moment when the priests invoke the Spirit, heaven opens and the Spirit descends and hovers over the water," Dem. 6.14 (Parisot, Aphraatis, I.292.25-I.293.1).

${ }^{15}$ I have intentionally left the phrase ruha naphshanayta untranslated here, but I will define it in the subsequent discussion.

${ }^{16}$ See for example Dem.17.6 (Parisot, Aphraatis, I.793.21-24): “[God] has honored, exalted, and glorified human beings more than all creatures because he has molded them with his holy hands and he breathed into them

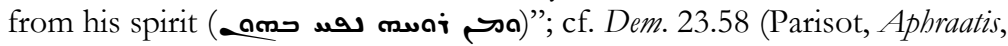

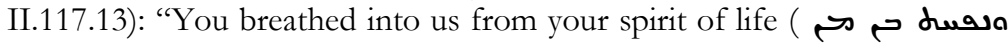

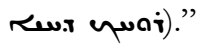


translations of Gen 2:7.17 It is possible that he creatively and intentionally chose the more flexible word rwai, though it is also possible that he conflated this passage with John 20:22 in which Jesus breathed on the disciples and told them to receive the Holy

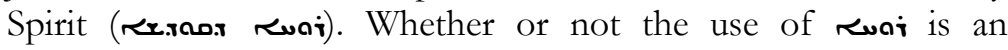
intentional change to the received wording, however, it is clear that Aphrahat deliberately established a link between the 'spirit'/'breath' (ruai) of God and the rowras rwai of humanity.

Thus far our discussion has left untranslated the key phrase for parsing Aphrahat's view of the body and soul, rdwra rwai, because it is not immediately clear what Aphrahat intended by it. The difficulty in rendering this phrase correctly is grounded in the fact that Aphrahat used two words whose layers of meaning overlapped, with د ('soul/self') being employed as an adjectival modifier of ruai ('spirit'). Most modern translators, agreeing with Parisot's Latin translation that accompanies the primary printed text of Aphrahat's Demonstrations, render the phrase as "animal/animate" or "natural" spirit. ${ }^{18}$ It is possible that Aphrahat is adapting Paul's language from

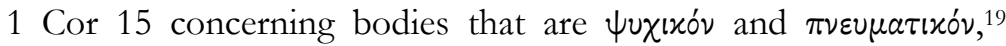
applying the distinction to the soul rather than the body. However, this would be a rather surprising argument if that's what Aphrahat intended. The translation of the phrase as 'natural/animal spirit' while not incorrect-does not necessarily tell us what Aphrahat had in mind when he used the phrase rowras rwai. Indeed, the broader context of this argument suggests that when Aphrahat employed this phrase, he actually just meant 'the soul.'

${ }^{17}$ The three main Aramaic Targum translations of Genesis (Onqelos, Ps.-Jonathan, Neofiti) used נשמתא in Gen 2:7.

18 Parisot (Aphraatis, I.294) renders it as "spiritus animalis"; Valavanolikal: "animate spirit" (Aphrahat, Demonstrations I, 152-153); Lehto translates "natural spirit" (Demonstrations, 192); and Pierre renders it as "esprit animé" (Les Exposés, I, 401). In his German version, Peter Bruns breaks from this trend and translates this phrase more idiomatically as "sinnenhafte Geiste" (a "sensing spirit"); Bruns, Aphrabat: Unterweisungen, I, 205.

${ }^{19}$ Indeed, in the broader context, Aphrahat argued that the 'natural

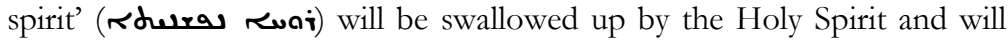
become 'spiritual' (نصar). This language matches the Syriac translation of

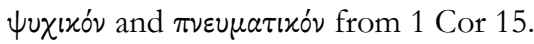


That this is the case can be demonstrated in two ways: first, Aphrahat associated this entity with a property that was characteristic of the soul in ancient philosophical discussions of the body and soul: the capacity for sense perception. Immediately following the comparison of creation and baptism, Aphrahat asserted, "When people die, the rowras rwai is buried with the body and sensation/perception ( $\mathbf{r d r} \mathbf{i}$ ) is taken away from it." 20 The idea that the soul is the home for the capacity of sensation/perception ( $a$ l $\sigma \theta \eta \sigma \iota s$ ) in Greek philosophy is at least as old as Aristotle, ${ }^{21}$ and it also appears in Stoic thought. ${ }^{22}$ Galen attributed the capacity for perception to the í $\gamma \varepsilon \mu o v i x o$ s, the "ruling part" of the soul, ${ }^{23}$ although he disagreed with the Stoics concerning its location within the body. On the topic of body and soul, Galen's writings were influential for later writers, both pagan ${ }^{24}$ and Christian. ${ }^{25}$ The specific correlation of sense perception with the soul also appears in the middle-Platonic, Jewish exegesis of Gen 2:7, as evidenced by the writings of Philo of Alexandria. ${ }^{26}$ Thus, by attributing the concept of rdri i to the rowes rwai, Aphrahat's writings reflect a general

${ }^{20}$ Dem. 6.14 (Parisot, Aphraatis, I.293.12-14).

${ }^{21}$ Aristotle, De anima I 1.403 (edition: R.D. Hicks, Aristotle, De Anima [Cambridge: University Press, 1907]); although, Aristotle clearly did not think that the soul had capacity for sensation apart from the body.

22 Cf. Ps.-Plutarch, Placita Philosophorum 4.23 (edition: William W. Goodwin, Plutarch's Morals [Boston: Little Brown and Company, 1878]): "For the Stoics, the passions are in the affected parts [of the body], but the

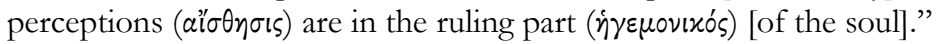

${ }^{23}$ Galen, De Placitis Hippocrates et Platonis, II.3.4ff; text and edition: Phillip de Lacy, Corpus Medicorum Graecorum Vol. 4,1,2: Galeni, De Placitis Hippocratis et Platonis (Berlin: Akademie Verlag, 2005).

${ }^{24}$ In particular, Galen was influential for Plotinus and the neo-Platonic tradition; cf. Teun Tieleman, "Plotinus on the Seat of the Soul: Reverberations of Galen and Alexander in Enn. IV, 3 [27], 23," Phronesis 43.4 (1998), 306-325.

${ }^{25}$ Galen was one of the primary sources for the fourth-century author Nemesius of Emesa's De natura hominis.

${ }^{26}$ Questions and Answers on Genesis, I.4-5 (edition: Ralph Marcus, Philo, Supplement I: Questions and Answers on Genesis [Cambridge: Harvard University Press, 1953], 3-4); cf. On the Creation of the Cosmos, I.18-19 (edition: David T. Runia, Philo of Alexandria: On the Creation of the Cosmos according to Moses, Introduction, Translation, and Commentary [Leiden: Brill, 2001], 82-86). 
knowledge of prior and contemporary philosophical concepts of the soul and its relationship to the body. ${ }^{27}$

Beyond the recognition of his association of sense perception with the rowra suai, it is also clear that Aphrahat used this term in reference to the soul based on his description of what happens to this entity at death and then at the resurrection, namely that the ruai rowras would be buried along with the body. Thus, Aphrahat teaches the concept of the "sleep of the soul." Although Aphrahat did not explicitly state that the soul "sleeps," he did argue that it is buried ( $($ ris is removed from it. Thus, the soul remains with the body and exists in some kind of unconscious state. ${ }^{29}$

Aphrahat expressed his belief in the sleep of the soul even more clearly when he returned to this topic in Dem. 8 ("On the Resurrection of the Dead") and contrasted the "sleep" of the righteous and the wicked in the time between death and the resurrection. He employed here an analogy of good and bad servants who are sleeping: the bad servants do not sleep well and do not wish to arise because they know that their master will punish them when they do wake up. The good servants, however, sleep soundly, knowing the rewards that await them. Aphrahat concluded the analogy thus:

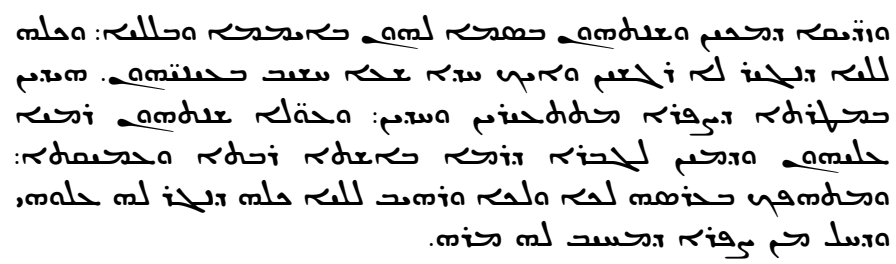

The upright lie down and their sleep is pleasant, throughout day and night. For they do not perceive the whole night to

${ }^{27}$ Unfortunately, Aphrahat did not expand on this topic at all, making it virtually impossible to identify any "sources" he may have known or relied on for his view of the soul. It seems best to conclude that he was simply reflecting a sort of "common knowledge" about the properties of the soul.

${ }^{28}$ The meaning of the root word is is ito hide,' but the passive form (ethpe'el) that Aphrahat employed here is generally translated as 'buried'; cf. M. Sokoloff, A Syriac Lexicon (Piscataway, NJ: Gorgias Press, 2009), 537.

29 As Pierre asserts, "Il n'y a plus connaissance ni discernement," Éxposes, vol. 1, 184. 
be long, but experience it as though it were a single moment. Then, when the morning comes, they wake up and rejoice. The sleep of the wicked, however, lies heavily upon them, like a man stricken with a strong, deep fever who tosses and turns on his bed, and who is disturbed throughout the long night. They fear the morning, when their master will condemn them (Dem. 8.19). ${ }^{30}$

Following this passage, Aphrahat re-emphasized the point that, although the sleep of death may or may not be pleasant, human beings are not conscious during the period of death before the resurrection. Aphrahat argued that when the resurrection takes place, the rowras rwor will be raised along with the body and, at least for the righteous, will be transformed with the body into its "spiritual" state: "The rowras rwoi will be swallowed up in the heavenly Spirit and the whole person will become spiritual since the body is in the spirit." 31 Those who are not righteous, however, will not be changed; instead, they remain in their "natural" (shwra) condition. ${ }^{32}$ When the transformed righteous ones are taken away to heaven, the unrighteous, who are not transformed, remain on Earth and descend to Sheol.

Aphrahat's distinction between the "righteous and unrighteous" in death and at the resurrection raises the question of what qualifies a person to be called "righteous." In Aphrahat's estimation, each person must maintain the purity of the Holy Spirit ${ }^{33}$ that was received at the moment of baptism. That is, when someone dies and their soul and body are buried, the portion of the Holy Spirit that dwelled in that person from the time of baptism returns to its place with Christ and testifies either for or against the body it inhabited based on whether or not that person "guarded [it] in holiness." $34 \mathrm{It}$ is this testimony that determines each person's status in the resurrection.

30 Parisot, Aphraatis, I.397.3-14.

${ }^{31}$ Dem. 6.14 (Parisot, Aphraatis, I.296.26-I.297.2).

32 Aphrahat also called this the "created nature of Adam" ( דrar); Dem. 6:18 (Parisot, Aphraatis, I.309.12).

33 When speaking of this Spirit, Aphrahat varied the terminology he employed. He often used the phrases "Holy Spirit," "Spirit of Christ," "Spirit of God," and just "Spirit" interchangeably.

${ }^{34}$ Dem. 6.14 (Parisot, Aphraatis, I.293.24-I.296.7). 
This particular argument is intriguing for the perspective it offers regarding Aphrahat's view of the body/soul relationship. While Aphrahat believed in a bipartite human existence (with no distinction between a human 'soul' and 'spirit'), he argued nevertheless that baptized Christians have a tripartite existence: body, soul, and (Holy) spirit. He even implies that this portion of the Holy Spirit that returned to be with God maintained some sense of the individual identity of each person with whom it was associated. This is presumably how Aphrahat reconciled his understanding of the sleep of the soul after death with an assumed belief that the righteous would be in the presence of Christ immediately upon death. ${ }^{35}$ Indeed, Aphrahat apparently felt the need to defend his concept of the sleep of the soul against those who were claiming that people experienced either reward or punishment immediately upon death: "Those with childish minds say, 'if no one has received a reward, why did the apostle say, "When we depart from the body, we will be with the Lord"?"'36

The short discussion provided above offers an overview of Aphrahat's language and view of the soul/body relationship and of what will happen to the body and soul in death and at the resurrection. We may isolate at least three unique features of Aphrahat's views: the origin of the soul from the breath of God, the concept of the sleep of the soul, and the Holy Spirit's role in the life of the baptized Christian and in the resurrection. Aphrahat's distinct perspective emerges more clearly when juxtaposed with the views on such matters among contemporary religious communities.

\section{THE BREATH OF GOD AND THE SOUL OF HUMANITY}

Among various religious groups of late antiquity, many different competing interpretations of the creation narrative circulated. Thus it is not surprising that the subject of the soul in Gen 2:7, one of the key Scriptural passages for Aphrahat's argument, was the subject of multiple interpretive traditions in a range of other authors and texts. The hermeneutical conclusion that the breath of God actually

35 As Aphrahat argued, "The [Holy] Spirit returns to its natural condition with Christ [i.e. at death], for the apostle also said, "When we depart from the body we will be with our Lord' (2 Cor 5:8)," Dem. 6.14 (Parisot, Aphraatis, I.293.18-21).

${ }^{36}$ Dem. 8.23 (Parisot, Aphraatis, I.404.1-4). 
became the soul of humanity is at least as old as Philo of Alexandria, who argued in his work On the Creation that "the soul originated from the Father and ruler of all, for that which [God] breathed into [humanity] was nothing other than Divine breath." 37 It is also worth noting that Philo explicitly linked this interpretation of Gen 2:7 with the capacity for sense-perception $(\alpha / \sigma \theta \eta \sigma / \zeta)$.

The Jewish pseudepigraphical work known as $4 \mathrm{Ezra}^{38}$ also briefly mentions the association between God's breath and the animation of Adam's body. Although the precise date for the composition (most likely in Hebrew) of 4 Ezra is difficult to discern, it was certainly circulating in Greek translation by the end of the second century because Clement of Alexandria cites it explicitly. ${ }^{39}$ The presumed original Hebrew text does not survive at all, and the Greek translation is only partially attested. Thus, the Syriac version 40 represents one of the earliest witnesses to the full text of 4 Ezra. The text in question is found in 4 Ezra 3:5: “....and it [i.e. the dust/ground] gave to you Adam, a lifeless [lit. 'dead'] body" ( $\mathbf{R}$ i rdes). And yet, he was the work of your hands, so you breathed into him the breath of life (ivi), and he came alive ( Rama (w) before you." 41 A similar sentiment is also found in one Qumran poetic text, 4Q381: "And by his breath, [God] made them (i.e. Adam and Eve) stand..." ${ }^{42}$ Neither of these Jewish texts explicitly names

${ }^{37}$ Philo, On the Creation of the Cosmos, 18.134-135 (Runia, Philo: On the Creation, 82); elsewhere, this sentiment is even more explicit: "and [the molded man] obtained a spirit when God breathed life into his face," Questions and Answers on Genesis, I.4 (Marcus, Philo: Supplement I, Questions and Answers, 3-4).

38 This text, along with 5 Ezra and 6 Ezra, is also known as 2 Esdras. For a detailed discussion of the text and transmission of this work, see Michael Edward Stone, Fourth Ezra (Minneapolis: Fortress Press, 1990), 1 8 .

39 Stone, Fourth Ezra, 9.

${ }^{40}$ Preserved only in the famous seventh century Peshițta manuscript Codex Ambrosianus B.21 (also known as 7a1). For a modern edition of the text, see R. J. Bidawid, "4 Esdras," in The Old Testament in Syriac according to the Peshitta Version, IV,3: Apocalypse of Baruch, 4 Esdras (Leiden: Brill, 1973).

${ }^{41}$ Syriac text from Bidawid, "4 Esdras," 1; translation is my own.

42 וברוחו העמידמ, 4Q381, Frag. 1, line 7; “4Q381 (4QNon-Canonical Psalms)," ed. by E. Schuller, in The Dead Sea Scrolls Reader, Part 5: Poetic and Liturgical Texts, ed. by Donald W. Parry and Emanuel Tov (Leiden: Brill, 2005), 154-155. 
"the soul," yet it is clear that both view God's breath as the animating force of the otherwise lifeless body of Adam.

The interpretive tradition that linked the breath of God to the soul of humanity is also found in later Jewish literary traditions. Two of the Aramaic Targum translations of Genesis incorporate this interpretation directly into their wording of Gen 2:7:

Targum Onqelos to Genesis 2:7

\section{ונפח באפוהי נשמתא דְחיי והות באדם לרוח ממללא43}

"And [God] breathed into [the nostrils] of his face the breath of life, and it became in Adam a spirit uttering speech." 44

Targum Pseudo-Jonathan to Genesis 2:7

\section{ונפח בנחירוהי נשמתא דחיי והוות נשמתא בגופא דאדם לרוח ממללא לאנהרות עינין ולמצתות אודנין45}

"And [God] breathed into his nostrils the breath of life, and the breath became in the body of Adam a spirit capable of speech, to give light to the eyes and hearing to the ears." 46

The fact that both Targum Onqelos and Targum Ps.-Jonathan state explicitly that the breath (נשמתא) of God became the soul of humanity likely indicates that this was an already well-established interpretive tradition in Jewish interpretation by the time period roughly contemporary with Aphrahat (i.e. $4^{\text {th }}-5^{\text {th }}$ century) ${ }^{47}$ However, as with

43 Aramaic text from Moses Aberbach and Bernard Grossfeld, Targum Onkelos to Genesis (Hoboken: Ktav Publishing, 1982), 29.

${ }^{44}$ English translation from Bernard Grossfeld, The Targum Onqelos to Genesis, The Aramaic Bible 6 (Wilmington: Michael Glazier, 1988), 44.

45 Aramaic text from E.G. Clarke, et al, Targum Pseudo-Jonathan of the Pentateuch: Text and Concordance (Hoboken: Ktav Publishing House, 1984), 2.

46 English translation from Michael Maher, Targum Pseudo-Jonathan: Genesis, The Aramaic Bible 1B (Collegeville: Liturgical Press, 1992), 22.

47 There is significant debate concerning the dating of Targum Onqelos, particularly over the question of the existence of a 'protoOnqelos' known in Palestine, which would then suggest a two-stage composition for the Targum with the first stage taking place in the first two centuries of the common era and the second stage taking place in Babylonia 
Aphrahat, it is not immediately clear that this is a reference to the soul because the Targumim state that the breath of God became a (a "spirit capable of speaking") and Ps.-Jonathan also adds the senses of sight and sound. Thus, although it is clear that the Targum translations relate the capacities of the senses to the רוחא that resulted from the breath of God, it is necessary to explore the Rabbinic tradition more widely in order to establish that the soul is the intended subject here.

The midrashic interpretation of Gen 2:7 in Bereshit Rabbab $(B e r R)$, a text generally dated to the fifth century, ${ }^{48}$ is informative here for several reasons. First, BerR also explicitly linked the breath of God to the soul of humanity in the interpretation of the phrase ויפח באפיו ("and [God] breathed into his nostrils"): "This teaches that

by the end of the fourth century. For a concise summary of the scholarly question on this matter, see Paul V.M. Flesher and Bruce Chilton, The Targums: A Critical Introduction (Leiden: Brill, 2011), 83-87 and 109-129. Other scholars argue for an even more specific date for the final edit in the third century based upon the evidence of the masorah, which is dated to the first half of the third century; see Bernard Grossfeld, The Targum Onqelos to Genesis, 30-32.

The dating of Targum Pseudo-Jonathan (also known as Targum Yerushalmi) is even more difficult because there are clearly elements that are post-Islamic (see Flesher and Chilton, The Targums, 88). However, this does not suggest that the whole Targum was composed after the advent of Islam, as it is more likely that some passages simply represent a late redaction. While it appears that Pseudo-Jonathan is reliant upon Onqelos, it is also apparent from an examination of Targumic citations in the Palestinian Talmud that both Onqelos an Pseudo-Jonathan were known to Rabbis by the fifth century at the latest; see Flesher and Chilton, The Targums, 131-150, 157-158. For an even more specific treatment of the dating of Pseudo-Jonathan, with argues also for a late fourth-century/early fifth-century date, see Robert Hayward, "Red Heifer and Golden Calf: Dating Targum Pseudo-Jonathan," pages 9-32 in Paul V.M. Flesher, ed., Targum Studies, Vol. 1: Textual and Contextual Studies in the Pentateuchal Targums (Atlanta: Scholars Press, 1992). Other scholars, however, such as Michael Maher, still accept a later dating of Pseudo-Jonathan and argue that it was edited into its final form no earlier than the $7^{\text {th }}-8^{\text {th }}$ centuries; see Maher, Targum Pseudo-Jonathan: Genesis, 11-12.

${ }^{48}$ For a discussion of the problems with dating this text, see H.L. Strack and Günter Stemberger, Introduction to the Talmud and Midrash, translated by Markus Bockmuehl (Minneapolis: Fortress Press, 1992), 279280. 
[God] set him up as a lifeless mass, reaching from earth to heaven and then infused a soul (נשמה) into him." 49 This text certainly adds support to Rabbinic evidence for the belief that the breath of God became the soul of humanity. Yet it also adds a layer of linguistic difficulty because it employs the term נשמה for soul. That multiple Hebrew and Aramaic words could be used in Rabbinic literature for the concept of 'the soul' is likely a result of the fact that the Hebrew Bible itself employed a range of words for the soul. Indeed, the editor(s) of BerR was well aware of this issue and addressed it explicitly. Immediately following the quotation given above, the text of BerR includes a discussion of the five "names" of the soul used in

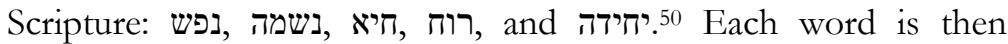
explained by referencing the passages where it appears in the Hebrew Bible.

The exegetical principle that can be derived from this passage from BerR is as follows: 1) these five words were used interchangeably for the concept of the human soul, as demonstrated by the passages mentioned; 2) one of these five words was used to speak of the "breath" of God; 3) therefore, each of these words could refer either to the breath of God or to the human soul. If there were any doubt that this was the guiding principle at work here, it is made explicit just a few lines later in the context of the discussion of the phrase ויהי האדם לנפש חיה ("And Adam became a living soul”):

R. Samuel, the son-in-law of R. Hanina, the colleague of the Rabbis, said: here the נשמה is identified with 2:7), whereas in another text the נשמה is equated with רוח (Gen $7: 22$ ). How do we know that the statement of the one text is applicable to that of the other and vice versa? Because חיים is written in both texts, proving that they are analogous (BerR 14.10).51

${ }^{49}$ BerR 14.8; Midrash Rabbah, 2 Vols: Genesis I, Genesis II, trans. by Rab. H. Freedman (New York: The Soncino Press, 1983), Vol. 1, 116. All English translations of BerR in the present paper are taken or adapted from this edition.

50 BerR 14.9; Freedman, Midrash Rabbah, Genesis I, 116. The text of Midrash Rabbah throughout this essay comes from J. Theodor, Bereschit Rabba, 3 Volumes (Berlin: Akademie Verlag, 1912-1927).

${ }^{51}$ Freedman, Midrash Rabbah, Genesis I, 118. 
The lexicographical conclusion, and thus the exegetical conclusion of BerR is: נשמה = נפש = רוח, not only because these words are used interchangeably in various passages of Scripture, but even more so because each is used in conjunction with חיים.

The Rabbis were not the only ones who preserved a tradition of the breath of God becoming the soul of humanity. This concept also appeared in various texts from other early Christian communities. Irenaeus of Lyon, for example, stated that "the breath of life that came from God" animated Adam and bestowed upon him the capacity for reason..$^{52}$ Although Irenaeus did not explicitly mention the soul, it seems clear from the context of the argument that this is what he had in mind. This view is also present within writings that were not accepted as authoritative in the later development of "orthodox" Christianity. The Apocryphon of John, ${ }^{33}$ for example, also includes this tradition in its telling of the creation narrative: "And they said to Yaltabaoth, 'Blow into his face something of your spirit $(\square \square \square \square \bar{\square} \bar{C})$ and his body will arise.' And he blew into his face his spirit, which is the power of his Mother...and the power of the Mother went out of Yaltabaoth into the psychic body (?]?!??]????? $\square \square \square \square \square$ ), which they had fashioned after the image of the one who exists from the beginning. The body moved and gained strength, and it was luminous." 54 Again, although this text does not include an explicit word for "soul," it clearly implies that the divine breath that Yaltabaoth blew into the created body of man was the force that animated the body. Likewise, this sentiment appears in the texts

52 Latin: "ea quae fuit a Deo aspiration vitae...et animal rationabile ostendit," Irenaeus, Adv. Haer, 5.1.3; for the Latin text, see Norbert Brox, Irenäus von Lyon, Adversus Haereses_Gegen die Häresien, Vol. 5, Fontes Christiani (Freiburg: Herder, 2001), 30.

53 This text is sometimes also referred to as The Secret Book according to John (BJn). For synoptic text and translation, see The Apocryphon of John: Synopsis of Nag Hammadi Codices II,1; III,1; and IV,1 with BG 8502,2, ed. by Michael Waldstein and Frederick Wisse, Nag Hammadi and Manichaean Studies XXXIII (Leiden: Brill, 1995), 12-177.

${ }^{54}$ Ap. Jn. II.19.22-28; Waldstein and Wisse, Apocryphon of John, 114-115. Moreover, Irenaeus of Lyon repeated this belief and attributed it to part of the general "Gnostic" creation myth; see his Adv. Haer. I.30.6; Norbert Brox, Irenäus von Lyon: Epideixis, Adversus Haereses_Darlegung der apostolischen Verkündigung, Gegen die Häresien, Vol. 1, Fontes Christiani (Freiburg: Herder, 1993), 336-338. 
known as Hypostasis of the Archons ${ }^{55}$ and Trimorphic Protennoia. ${ }^{6}$ All of these texts, as with many Coptic texts in the Nag Hammadi collection, are quite difficult to date because the original Greek versions have not survived. It is certain, however, that these texts predate the mid-fourth century because the codices that contain these texts are dated to the middle of the fourth century..$^{57}$ Thus, even though we cannot date these texts precisely, we can say that these ideas were circulating in various texts by at least the first half of the fourth century, which is also the precise date range of Aphrahat's writings. Based on the evidence provided by Rabbinic materials, various early Christian writings, and Aphrahat himself, we can quite confidently conclude that there was a well-established, yet malleable interpretative tradition of associating the breath of God in the creation story of Genesis with the origin of the human soul. It is certainly not necessary to claim that Aphrahat knew of or used any of these texts as "sources" for his own argument, but this broader literary context allows us to consider Aphrahat's ideas as part of a complex interpretive tradition that spans a large geographic and ideological range.

${ }^{55}$ Hyp. Arch. 88.3-5: "And he breathed into his face; and the man came to have a soul (]????????]) [and remained] upon the ground many days." Bentley Layton, ed., "The Hypostasis of the Archons," in Nag Hammadi Codex II,2-7, Vol.1, ed. by Bentley Layton, Nag Hammadi Studies XX (Leiden: Brill, 1989), 238-239. This text goes on to say, however, that the man only became a "living soul" (따?]?? [?]??????) when the Spirit came and dwelt in the "soul-endowed man" ( $\square \square \square \square \square \square \square \square \square \square \square \square \square \square \square$ ). In this way, even though this text reflects a shared hermeneutical tradition with Aphrahat, there are significant differences in the applications of this hermeneutic because of the varied contexts in which these texts were produced.

56 Tri. Prot. 45.28-29: "It is I who put the breath within my own. And I cast into them the eternally holy Spirit...”John D. Turner, ed., "Trimorphic Protennoia," in Nag Hammadi Codices XI, XII, XIII, ed. by Charles W. Hedrick, Nag Hammadi Studies XXVIII (Leiden: Brill, 1990), 422-423.

${ }^{57}$ The Apocryphon of John was certainly circulating as early as the second century because, as noted above in fn. 47 , it is one of the major sources of Irenaeus' polemic against the gnostics, and he quotes from it extensively. 


\section{SLEEP OF THE SOUL}

While it is relatively easy to adduce potential parallels from other writers that can be compared fruitfully to Aphrahat's interpretation of Gen 2:7, it is quite difficult to contextualize Aphrahat's argument in favor of the "sleep of the soul." This concept is not prevalent in early Christian interpretations of death and the resurrection, and it is difficult to find points of exegetical comparison because Aphrahat does not necessarily link the idea of the sleeping soul to a specific passage of Scripture. While some Jewish writings ${ }^{58}$ do speak of dead bodies "sleeping," there is very little evidence prior to Rabbinic interpretation that Jews believed in the "sleep of the soul" with the body as Aphrahat describes it. There is, however, a fairly strong tradition in both Second Temple and Rabbinic literature of Jewish belief in "treasuries" where the soul would be kept in a state of rest until the time of the resurrection. 59

There is one Rabbinic text that might suggest a belief in the "sleep of the soul," but the broader Rabbinic tradition complicates this text and makes it difficult to conclude that it represents the position of the Rabbis more generally. The text in question, also from Bereshit Rabbah, offers an exegesis of Abraham's death (Gen $25: 8$ ) that brings up the topic of a righteous person's knowledge of the reward to come before death, which results in a pleasant experience of death. The specific passage from this text for the present topic is: "The entire reward of the righteous is kept ready for them for the hereafter, and the Holy One, blessed be He, shows them while yet in this world the reward $\mathrm{He}$ is to give them in the future; their souls (נפשם) are then satisfied and they fall asleep (ישינים).".00

It is possible to conclude, based on the language of sleep and the explicit mention of souls, that this passage represents a belief in the sleep of the soul. The parashah continues by offering the metaphor of a king who invited his guests to view the meal they would eat, after which the guests, so satisfied by what they had seen,

${ }^{58}$ Dan. 12:2; cf. 4 Ezra 7:32: "And the earth shall give back those who are asleep in it, and the dust those who rest in it."

59 The concept of "treasuries" for the souls of righteous people is frequent in 4 Ezra, including 4:35, 41; 7:32, 80, and 95. See also 2 Apoc. Bar. 21:23; Sifre Deut. 33:3.

${ }^{60}$ BerR 62.2; Freedman, Midrash Rabbah, Genesis II, 549. 
fell asleep peacefully. ${ }^{61}$ Then it concludes with the following explanation: "So does God show the righteous while yet in this world the reward which $\mathrm{He}$ is to give them in the future, and thus they fall asleep with satisfied souls." While it is tempting to associate this passage with a doctrine of soul sleep, this is not a necessary conclusion, given that sleep-terminology is frequently employed as a metaphor for death in the Hebrew Bible. ${ }^{62}$ Even if this passage did provide clear support for the sleep of the soul, the broader Rabbinic tradition stands in direct contradiction with this teaching.

Although there are several texts that could be used to demonstrate this point, perhaps the clearest statement of the Rabbinic position on what happens to the soul/body relationship at death appears in the Talmud in tractate Berakoth:

When one wakes he says: 'My God, the soul that you placed in me is pure. You fashioned it in me, you breathed it into me, and you preserve it within me. And one day you will take it from me and then restore it to me in the time to come. So long as the soul is within me I give thanks unto you, O Lord, my God, and the God of my fathers, Sovereign of all worlds, Lord of all souls. Blessed are you, O Lord, who restores souls to dead corpses.' (bBer 62b)

This passage explicitly states that the soul will be taken from the body (presumably at death) and that it will be restored in the "time to come." Perhaps in order to emphasize that death is the moment at which the separation takes place, the passage continues by stating that souls are restored to "dead corpses." Moreover, in addition to this text, we may also refer to the Rabbinic distinction between what will happen to the souls of the righteous and the souls of the wicked, which presupposes that souls will be separated from bodies at

${ }^{61}$ A parallel passage in Exodus Rabbah 52.3 (on Exod. 39:33) repeats the concept of the righteous seeing their reward before death, and even uses the same passage as a cross reference (Prov. 31:25), but the reference to sleeping souls is entirely absent; S.M. Lehrman, Midrash Rabbah, Exodus (New York: Soncino Press, 1983), 575-577.

${ }^{62}$ Cf. Ps 13:3; 90:5; Dan 12:2; Job 14:10-14; Jer 51: 37-39, 56-67. For extra biblical references to the concept of sleep in ancient Jewish thought, see Chapter 4 ("Peace, Sleep, and the Just") in Joseph S. Park, Conceptions of Afterlife in Jewish Inscriptions (Tübingen: Mohr Siebeck, 2000), 87-121. 
death. ${ }^{63}$ Thus, although there is one Rabbinic text that could be interpreted in support of the sleep of the soul being an idea known among the Rabbis, the broader Rabbinic tradition shows that such a view was not widely known or accepted. Moreover, even if the text from BerR is representative of an earlier strand of Rabbinic thought that did, in fact, support belief in the sleep of the soul, it is not necessary to conclude that Aphrahat was aware of this interpretive tradition because Aphrahat's hermeneutical framework for soul sleep has virtually nothing in common with that of BerR.

The doctrine of the sleep of the soul does not appear to have been prevalent among early Christian writers, though Tatian and Origen provide limited data to show that this idea circulated among at least some early Christians. In his Oratio ad Graecos, Tatian argued that some souls (specifically the souls that are "ignorant of the

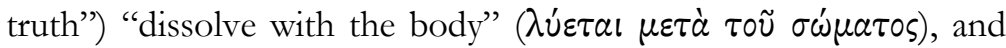
that these souls would rise again with the body for eternal punishment. ${ }^{64}$ For Tatian, though, there is a distinction between the souls who are "ignorant of the truth" and those who attain "union" with the divine Spirit; the souls of the latter are not buried with the body because they are led to heaven by the Spirit. ${ }^{5}$ Thus, Tatian's concept of the sleep of the soul exhibits at least one major difference from Aphrahat, who teaches that all souls will be buried with their bodies, but that the righteous souls/bodies would be transformed after the final judgment. Origen explicitly rejects the idea that the soul remains with the body after death in the Dialogue with Heraclides. ${ }^{66}$

${ }^{63}$ See Talmud tractate Shabbath (bShab) 152b; The Babylonian Talmud, Seder Mo'ed, I: Shabbath, trans. by I. Epstein (London: Soncino Press, 1938), 778-780; see also the parallel midrash in Qobelet Rabbah (QobR) 12.1 (par. 6); A. Cohen, Midrash Rabbah, Ecclesiastes (New York: Soncino Press, 1983), 303-304.

64 Tatian, Oratio ad Graecos 13.1 (Molly Whittaker, Tatian: Oratio ad Graecos and Fragments, Oxford Early Christian Texts [Oxford: Clarendon Press, 1982], 27). For a more recent edition and survey of this text along with a German translation, see Jörg Trelenberg, Tatianos: Oratio ad Graecos, Rede an die Griechen, Beiträge zur historischen Theologie 165 (Tübingen: Mohr Siebeck, 2012).

${ }^{65}$ Tatian, ad Gr 13.2 (Whittaker, Tatian, 27).

${ }^{66}$ For the Greek text and French translation, see Jean Scherer, Origène: Entretien avec Héraclide, Sources Chrétiennes 67 (Paris: Les Éditions du Cerf, 2002). For English translation, see Robert J. Daly, Treatise on the Passover. 
In this dialogue, Origen addresses those "who say that the soul remains in the tomb with the body," and then refutes this claim by referring to a series of Scripture passages that he interprets as proof of the soul's immediate departure from the body at death. ${ }^{67} \mathrm{It}$ is likely ${ }^{68}$ that this dialogue is the basis for Eusebius' claim that Origen had a dispute with some Christians in 'Arabia' on the topic of the soul at death. ${ }^{69}$ Beyond these two authors, the doctrine of soul sleep is not common in early Christian sources. ${ }^{70}$ However, as Peter Bruns points out, it is possible that Aphrahat is simply reflecting a view that was present in some biblical and early Jewish texts. ${ }^{71}$ Although there are similarities between Aphrahat's views on the sleep of the soul and the ideas found in Tatian and Origen, it is not necessary to conclude that Aphrahat knew either of these sources or that his arguments should be equated with the views that Tatian and Origen discuss. However, given Tatian's Syrian background and the identification of Origen's opponents as Arabian, it is plausible that the idea of soul sleep circulated more widely among Christians in the Eastern Mediterranean.

Dialogue with Heraclides and bis fellow bishops on the Father, the Son, and the Soul, Ancient Christian Writers 54 (New York: Paulist Press, 1992).

${ }^{67}$ Origen, Dia.Her. 23.8-24.17 (Scherer, Origène, 100-102).

${ }^{68}$ On the identity of the opponents in the Dialogue with Heraclides and the possible association with this reference in Eusebius, see Scherer's introduction in Origène, 19-21.

${ }^{69}$ According to Eusebius, this teaching says that "the human soul dies for a while in this present time, along with our bodies, at their death, and with them turns to corruption; but that hereafter, at the time of the resurrection, it will come to life again along with them." Eusebius, Ecc.His. 6.39 (Eusebius: Ecclesiastical History, Books 6-10, translated by J.E.L. Oulton, Loeb Classical Library 265 [Cambridge: Harvard University Press, 1932], 90-91).

${ }^{70}$ In his article on the sleep of the soul in the early Syriac tradition, Frank Gavin attempts to relate Aphrahat's teaching to various passages from earlier Christian authors, such as Irenaeus, but these comparisons are not convincing; F. Gavin, "The Sleep of the Soul in the Early Syriac Church," Journal of the American Oriental Society 40 (1920): 103-120.

${ }^{71}$ Bruns lists Isa 26:19, Ps 22:30, Dan 12:2, 2 Esdras (4 Ezra) 7:32, and the Apocalypse of Baruch 50:2; Bruns, Aphrabat: Unterveisungen, I, 69. 


\section{BODY AND SOUL IN THE RESURRECTION}

One of the most significant, yet easily overlooked, aspects of Aphrahat's treatment of the resurrection is that it was accompanied by an apparent polemic against an unnamed opponent who taught a different doctrine of the resurrection. According to that opponent, there would be a resurrection, yet the body itself would not be raised. Although Aphrahat does not name this opponent explicitly, there are two clues that can, perhaps, provide some details about their identity. First, Aphrahat mentioned explicitly that the alternative teaching on the resurrection derived from a misinterpretation of the words of Paul in 1 Cor 15. ${ }^{72}$ As such, it is clear that this opponent takes the words of Paul as authoritative, which means that they are at least in some way affiliated with Christianity. The second piece of evidence that Aphrahat provided concerning the identity of this opponent is the reference to "deceptive teachings, instruments of

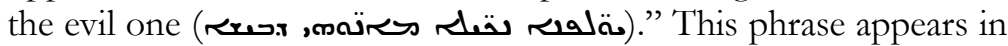
both Demonstrations 6 and 8 within the context of Aphrahat's defense of the bodily resurrection, which might suggest that he had a particular opponent in mind when using this phrase. Thus, it is

72 Dem. 6.18 (Parisot, Aphraatis, I.305.22-I.309.20) and 8.23 (I.404.119); these passages are discussed in more detail below. It is of course possible that Aphrahat is dealing with a Jewish opponent who had read Paul, but this is unlikely for several reasons: First, specific issues pertaining to Judaism only arise in the second set of Demonstrations (11-22), not in Demonstrations 1-10. Second, when Aphrahat is addressing a Jewish opponent in Demonstrations 11-22, he does so explicitly. There is no discernable reason that he would be coy about addressing Jews here if in fact they provided the alternative point of view. Third, the interpretation of 1 Corinthians 15 is known to have been contested among various Christian groups. As a result, the simplest historical explanation for Aphrahat's context is a rival Christian interpretation. In the absence of any explicit or implicit reference to a Jewish opponent, the simplest explanation here (a non-Jewish opponent) seems to be the best explanation. Finally, it seems unlikely that any Jews of Aphrahat's time period would have disagreed with Aphrahat on the topic of a bodily resurrection. See, for example, "Benediction 2" of the prayer of the Eighteen Benedictions, which expresses the basic belief in the resurrection; cf. BerR 14.5 (Freedman, Midrash Rabbah, Genesis I, 113-114) and the extensive apologetic discussion of resurrection beliefs in the Babylonian Talmud in tractate Sanhedrin (bSanb) 91; The Babylonian Talmud, Seder Nezikin, III: Sanhedrin, trans. by I. Epstein (London: Soncino Press, 1935), 607-614. 
worth pausing to consider whether this opponent can be identified more specifically.

Elsewhere in the Demonstrations, Aphrahat used this exact same

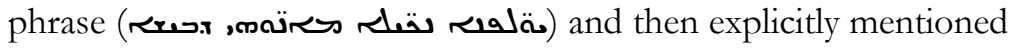
three teachers that fall under this category:

Observe that the deceptive schools, instruments of the Evil One, also fast and call to mind their sins, but there is no one to reward them. Who, indeed, will reward Marcion, who does not acknowledge our good creator? And who will reward Valentinus for his fasting, he who preaches that there are a number of creators, and who says that the perfect God cannot be described in words and that the intellect cannot examine him? And who will give reward to the sons of darkness, the school of the wicked Mani, who remain in darkness like serpents and engage in astrology, the teaching of Babylon? Behold, all of these fast, but their fast is not accepted. ${ }^{73}$

It is also worth noting that Ephrem the Syrian employed a similar phrase, הقلون ('erroneous teachings/teachers'), to describe Marcion, Bardaisan, and Mani. ${ }^{74}$ Indeed, Marcionite, Bardaisanite, and especially Manichaean communities are known to have existed in Persia in the fourth and fifth centuries, often in direct competition with communities that would come to be associated with orthodox Christianity. It is entirely possible-because of his repetition of this phrase in the polemical context of his treatment of the resurrection-that Aphrahat is directing this argument about the against one of these 'heretical' communities. However, because

${ }^{73}$ Dem. 3.9 (Parisot, Aphraatis, I.116.4-17). Note that the immediate context of this passage is the apologetic argument that these teachers or communities all practice fasting, but that their fast is 'not accepted.' Thus, Aphrahat depicted the respective teachings as being connected with ascetic practices that were also part of the life of his own community. Likewise, Aphrahat's contemporary, Ephrem, who wrote extensively against both Marcion and Mani, said of the Manichaeans: "Their works are like our works as their fast is like our fast, but their faith is not like our faith"; Mitchell, Prose Refutations, cxix.

${ }^{74}$ See, for example, the titles of the five "discourses" to Hypatius that make up part of Ephrem's Prose Refutations; see Mitchell, Prose Refutations, Vol. 1, 1. 
Aphrahat does not name a specific opponent, it is also possible that he was dealing with a misunderstanding among his own community, which may or may not have originated from one of these groups. The broader context of Aphrahat's exposition of this topic demands a more thorough examination in order to determine whether or not this opponent can be identified.

Although he is not mentioned by name in Aphrahat's list of evil teachers, one possible opponent that Aphrahat may have had in mind is the followers of Bardaisan. In a recent article, Thomas D. McGlothlin has made a strong case for identifying various aspects of Bardaisan's teachings that illuminate Aphrahat's argument about the resurrection in Demonstration $8 .^{75} \mathrm{McGlothlin}$ provides a very helpful "profile" of the opponents Aphrahat seems to describe, ${ }^{76}$ and then seeks to match this profile with depictions of Bardaisan's teachings that may have been available in the fourth century, including the Adamantius Dialogue and the polemical writings of Ephrem the Syrian. The key components of McGlothlin's profile are that Aphrahat's opponents seem to recognize the authority of the Old Testament (because Aphrahat appeals to arguments from it) and that they affirm the resurrection of the soul while denying the physical resurrection of the body. Ultimately, McGlothlin argues that these fourth-century constructions of Bardaisan's teachingsespecially that of Ephrem-fit well with the opponent Aphrahat seems to address. McGlothlin's depiction of Bardaisan's teachings also fits very well with Ute Possekel's reconstruction of Bardaisan's views on the resurrection, namely that Bardaisan likely taught the dissolution of the body, temporary death of the soul, and resurrection of the soul alone. ${ }^{77}$

McGlothlin's assessment of Aphrahat's opponent and comparison with Bardaisan's teachings is fruitful and certainly provides a plausible scenario. However, McGlothlin's only other point of reference in the article is the teachings of Origen of

75 Thomas D. McGlothlin, “Contextualizing Aphrahat's Demonstration 8: Bardaisan, Origen, and the Fourth-Century Debate on the Resurrection of the Body," Le Muséon 127 (3-4): 311-339.

${ }^{76}$ See esp. the summary paragraph on p. 317.

${ }^{77}$ Ute Possekel, "Bardaisan of Edessa on the Resurrection: Early Syriac Eschatology in its Religious-Historical Context," Oriens Christianus 88 (2004): 1-28. See also Possekel, "Expectations of the End in Early Syriac Christianity," Hugoye: Journal of Syriac Studies 11.1 (2011): 63-94. 
Alexandria, which were certainly circulating in polemical settings in the fourth century. McGlothlin goes on to make the case that the kinds of accusations Origen's later opponents made against his teachings do not fit as well with the profile of Aphrahat's opponents. On this matter, I certainly agree: if the choice of identifying Aphrahat's opponent is between the teachings of Bardaisan and Origen, the former certainly fits better than the latter. But if we explore options beyond Bardaisan and Origen, there are other plausible opponents whom Aphrahat may have engaged.

In his initial reference to the opponent's misinterpretation of Paul, Aphrahat addressed a specific issue: the interpretation of the "two Adams" in 1 Cor 15:44.78 Aphrahat's representation of what he thought was incorrect about this teaching is brief and vague. He merely claimed: "They say that there are two Adams." His subsequent exegetical exposition of Paul's verse also posited two Adams: the earthly Adam, created by God in the garden, and the heavenly Adam, "our Lord Jesus Christ." It is reasonable to conclude, then, that Aphrahat intended to prompt his readers to understand that the "two Adams" posited by his opponents were somehow different from his own interpretation. ${ }^{79}$

It is possible that Aphrahat was referring here to a teaching that maintained the "double-creation" of Adam, some form of which can be found in both Jewish and 'gnostic' Christian teachings. In BerR, for example, the midrashic interpretations of Gen 1:27 and 2:7 distinguish between the androgynous human form referred to in the former passage and the corporeal, earthly creation formed in the latter. ${ }^{80}$ Moreover, Philo also distinguished between the created objects in the two passages, and his distinction between them is even more pronounced. ${ }^{81}$ This idea of a double-creation also appears

${ }^{78}$ Aphrahat's citation of this verse reads, "The first Adam became a living soul, and the second Adam [became] a life-giving spirit"; Dem. 6.18 (Parisot, Aphraatis, I.308.1-2).

79 McGlothlin argues, using Ephrem's writings as a point of comparison, that Bardaisan's use of Adam-Christ typology from 1 Cor. 15 would have supported only a resurrection of the soul, not the body; McGlothlin, "Contextualizing Aphrahat's Demonstration 8," 324.

${ }^{80}$ Cf. BerR 8.1, 14.1, and 14.8; Freedman, Midrash Rabbah, Genesis I, 5455, 111, and 115-116.

81 On the Creation XII (section 69-70); Runia, Philo of Alexandria: On the Creation, 64 
within some versions of a gnostic creation narrative. According to Irenaeus's depiction, the gnostic creation myth included an initial creation of man followed by the gift of the divine breath and the subsequent addition of skin/flesh. ${ }^{82}$ There is nothing in Irenaeus' account, however, that links this interpretation to 1 Cor 15.

Another possibility is that Aphrahat may have been referring here to the Manichaean distinction between the "Primal Man" and the "second man," the latter of which could be interpreted either as the human Adam ${ }^{83}$ or as Christ. Indeed, there is evidence within Manichaean sources that some confusion existed about the distinction between and identity of the two figures. ${ }^{84}$ In Augustine's anti-Manichaean writings, there is a brief passage that also sheds some light on this discussion. In his debate with Faustus, Augustine argued:

Your Primal Man is not the first man of the apostle... [Augustine quotes 1 Cor 15:48-49] ... The first man of the earth is Adam, who was made of dust. The second man from heaven is the Lord Jesus Christ... Why do you conjure up this fabulous Primal Man of yours, and refuse to acknowledge the first man of the apostle? ... According to Paul, the first man is of the earth, that is, earthly; but according to Mani, he is not earthly, and he is equipped with five elements of some unreal, unintelligible kind. ${ }^{85}$

82 Irenaeus, Adv. Haer. I.5.5-6; for the Greek text, see Norbert Brox, Irenäus von Lyon: Epideixis, Adversus Haereses_Darlegung der apostolischen Verkündigung, Gegen die Häresien, Vol. 1, Fontes Christiani (Freiburg: Herder, 1993), 160.

${ }^{83}$ See, for example, the Manichaean hymn from Psalmbook 2, 141.1143.34 (Iain Gardner and Samuel N.C. Lieu, Manichaean Texts from the Roman Empire (Cambridge: University Press, 2004), 240-244.), which refers to the Primal Man and then the second man, Adam.

84 The Manichaean "Kephalaion 55," for instance, opens with disciples questioning Mani about Adam's creation in the form of "the ambassador." Iain Gardner, The Kephalaia of the Teacher: The Edited Coptic Manichaean Texts in Translation with Commentary (Nag Hammadi and Manichaean Studies 37; Leiden: Brill, 1995), 141.

${ }^{85}$ Augustine, Contra Faustum 2.4; Latin text: Saint Augustine, Opera Omnia $C A G$, [electronic edition] edited by Cornelius Mayer (Basel: Schwabe, 1995), part 3, 257.11-29. 
Within the broader context of Augustine's dispute, it becomes clear that the Manichaean depiction of "two Adams" did not have anything to do with the earthly Adam. Rather, according to Augustine, the Manichaeans asserted that Jesus was the son of the Primal Man. As a result, the "two Adams" of the Manichaeans were not Adam and Christ, but the Primal Man and Christ. This passage from Augustine provides an important comparison with Aphrahat because it shows that we have at least one other witness who explicitly critiques the Manichaean doctrine of the two Adams as a misinterpretation of 1 Cor 15 . This piece of evidence certainly does not prove that Aphrahat directed his argument against a Manichaean opponent, but it does show that ideas attributed to Manichaeans in other polemical literature could plausibly represent the viewpoint that Aphrahat critiques.

One further element of Aphrahat's presentation of the body/soul in the resurrection to be considered is his criterion for distinguishing between those who will be transformed at the resurrection into the perfected, heavenly form and those who will remain in their 'natural state.' The relevant criterion was whether or not a given person had maintained the Holy Spirit in purity. Aphrahat's language here sounds remarkably similar to that of the Rabbis, though of course Rabbinic sources discuss the importance of maintaining the soul, not the Holy Spirit, in purity. Two different Rabbinic texts, for instance, offer brief parable-like stories that illustrate the importance of maintaining the purity of the soul. In the first case, the example is a king who gives royal garments to his servants, some of whom return them in pristine condition, while others return them soiled. ${ }^{86}$ The second example is the story of a priest who gives a loaf of purified bread to another priest and expects it to be returned in pure condition. ${ }^{87}$ The concluding application of the latter parable, implied though not stated in the first, demonstrates the Rabbinic teaching quite well: "Similarly, the Holy One, blessed be He, said, 'Behold I am pure, my habitation is pure, my attendants are pure, and the soul that I gave you is pure. If you return it to me as I give it to you, well and good; otherwise, I will burn it in your presence." 88 This passage shows that within the Rabbinic tradition one can find ideas that are very similar to

86 bShab 152b; Epstein, Shabbath, 778-779.

${ }^{87}$ QobR 12.1 (par. 6); Cohen, Midrash Rabbah, Ecclesiastes, 303-304.

${ }^{88}$ QobR 12.1; Cohen, Midrash Rabbah, Ecclesiastes, 303. 
Aphrahat's language concerning maintaining the purity of the Holy Spirit and one also finds a clear connection of this need for purity in view of the reward of the afterlife that is to be obtained. Likewise, the text of 4 Ezra 7:78-99 also gives an extended discussion of the separation of and distinction between the souls of the righteous and unrighteous, but there is no indication that the person's individual soul or spirit plays any role in the judgment.

There is also a Manichaean text that provides an interesting point of comparison on this issue. One discussion found in the Manichaean Kephalaia provides a similar eschatological perspective that deals with the reward and punishment of the time to come. The key passage from this text that is of interest here provides a description of the "second death" for the unrighteous:

Now the second death is the death in which the souls of the sinful men shall die; when [they will] be stripped of the shining light that illuminates the world. And also, they are separated from the living air, from which they receive the living breath; and they are deprived of the living soul... because they have blasphemed the Holy Spirit since every generation of the world. ${ }^{89}$

This text explains that some will be punished in the life to come because they have blasphemed the Holy Spirit. Aphrahat explicitly warned his hearers not to 'grieve' the Holy Spirit in the context of his discussion of the resurrection; indeed, according to Aphrahat, the act of grieving the Holy Spirit is precisely what causes the Spirit to testify against people in the final judgment. We may also observe another similarity between this passage and Aphrahat's treatment of the resurrection: warnings about the second death. In Dem. 8, Aphrahat declared, "It is right for us, however, to fear the second death, which is full of weeping and gnashing of teeth, groans, and miseries, and which is situated in the outer darkness." 90

The similarities between this Manichaean material and Aphrahat's depiction of the judgment and resurrection are intriguing, but intriguing similarities are insufficient evidence to argue that Aphrahat was engaging Manichaeans directly. Moreover, as we have seen, Manichaeans were not the only community with

${ }^{89}$ Kephalaion 39 (102.13-104.20); Gardner, Kephalaia, 107-108.

${ }^{90}$ Dem. 8.19 (Parisot, Aphraatis, I.396.7-9). 
such intriguing similarities with Aphrahat's opponent. Thus, we must exercise caution in making definitive claims about the identity these opponents.

Even if specific arguments that Aphrahat makes about his opponents can be plausibly mapped onto historical reconstructions of particular teachers, we know very little about the ways that these teachings were transmitted in the early Syriac tradition. Likewise, we have very little data for how the communities that received these teachings would have attached specific ideas to particular teachers or how they would have identified themselves. It is s entirely plausible that ideas and concepts we as historians might identify as "Bardaisanite" or "Manichaean" or "Jewish" may have circulated freely among people for whom those labels would be artificial and inaccurate. The ideas that, over time, have come to be regarded as distinctly associated with a particular thinker or their followers may not have been rigid boundary markers between distinct religious identities in antiquity, particularly in the early period of development for Christian communities. The emergence of polemical literature, such as the anti-heretical writings of Ephrem in the late fourth century, attests to the construction of communal identity markers, and the attempt to associate particular heretical ideas with specific teachers plays a significant role in the formation of boundaries. In this regard, the polemical arguments that Aphrahat engages regarding the resurrection are not concerned with the construction of heretical and orthodox beliefs per se; that is, Aphrahat shows no desire to construct and thereby oppose a specific opponent. However, Aphrahat's argument does attempt to construct a logical, cohesive Christian theology of the soul/body problem, including the implications of that problem for the doctrine of the resurrection.

\section{CONCLUSION: APHRAHAT'S ANTHROPOLOGY IN CONTEXT}

While many of the texts discussed above shed some light on the various components of Aphrahat's depiction of the soul/body relationship, no single text or piece of information concerning a contemporary religious group suffices to enable the modern interpreter to explain his unique views. Rabbinic materials, and particularly the midrashic interpretations of Genesis, illuminate some concepts, but not others. Likewise, while it is clear that Aphrahat directed part of his polemic against some contemporary 
group engaged in the interpretation of Christian Scripture, the attempt to identify this opponent proves to be quite difficult.

If we resist the temptation to locate a specific opponent and instead focus on the broader milieu of religious and philosophical ideas about the body, the soul, and about what happens at death and the resurrection, it is possible to view Aphrahat's arguments as part of a larger conversation. Aphrahat engaged this conversation with some exegetical and hermeneutical traditions that were evident in preceding and contemporary religious communities, but he also provided a unique expression of those traditions based on the needs of his own community and his interpretation of Scripture. Thus, even if the context of Aphrahat's arguments do not provide enough information to correctly identify his opponent(s), the contours of the polemic do tell us something about Aphrahat's own community.

That Aphrahat felt the need to support his views with specific arguments against alternative exegetical conclusions suggests that his positions were not necessarily representative of everyone's views in his immediate community. One might be tempted to read his works as a straightforward depiction of his local expression of Christianity, and thus one might equate Aphrahat's beliefs with those of his community. However, if we search beneath the surface of Aphrahat's certainty about the issues he addressed, we find evidence of a Christian community whose particular dogmatic identity was not completely secure or defined. Indeed, perhaps Aphrahat should not be taken as the sole representative of a particular expression of Christianity that we might call a native 'Syriac' or 'Persian' Christianity. Rather his writings could serve as a witness to the diversity of Christian communities in the Persian milieu within which his works originated. Instead of thinking of separate, distinct religious communities with already defined beliefs and practices, it might be more productive to think of multiple Christian communities, lacking precise identity markers that would distinguish them from one another. In this regard, Aphrahat's writings might best be viewed as an attempt to articulate and shape the identity of a particular expression of Christianity by providing precisely such identity markers and dogmatic borders. ${ }^{91}$

91 What I am arguing here for Aphrahat is quite similar to, and influenced by, Christine Shepardson's treatment of Ephrem in her work Anti-Judaism and Christian Orthodoxy: Ephrem's Hymns in Fourth-Century Syria (Washington D.C.: The Catholic University of America Press, 2008). 
Aphrahat's arguments about the body/soul relationship offer a good example of how his writings might be viewed through this lens. His initial discussion of the topic of the body/soul and what happens at the resurrection is not an isolated, independent argument; it appears within the context of the Demonstration dedicated to the Bnay Qyama, a special group within Aphrahat's community of fellow believers who dedicated themselves to chastity. Aphrahat's discussion of how human beings receive the breath/spirit of God at creation and of how Christians receive the Holy Spirit at baptism is preceded by a survey of holy women and men, examples in the chaste life, who were able to lead such a life because of the power of the Holy Spirit. Moreover, Aphrahat's argument also carried a moral component when he went on to warn his audience that the Spirit could depart from them at any time, and that the Spirit would certainly depart from them in the case of sin. To complete this exposition, he informed his audience how they might retain the Spirit and not grieve her.92 Likewise, although Aphrahat's further exposition of his views about the resurrection in Demonstration 8 could have been a response to a specific opponent or controversy, his ultimate aim was to shape the beliefs of the members of his community: "Receive what I have explained to you, and believe that on the day of resurrection your body will rise up in its entirety. You will receive the reward for your faith from your Lord, and will rejoice and take delight in all that you have believed." ${ }^{3}$

There are multiple beliefs, practices, or traditions originating from various religious traditions that could have influenced Aphrahat's ideas: the bifurcation of a religious community into a small group of ascetic elites and a larger group whose members were not bound by the same strict ascetic demands was at the very core of Manichaean belief and practice; the concept of maintaining the Holy Spirit/Spirit of God in purity as the basis for eternal salvation appeared both in Rabbinic and in Manichaean thought; the idea of the sleep of the soul is attested by some early Christian witnesses, but does not seem to have gained much popularity; the wide ranging interpretive traditions of Gen 2:7 demonstrate the creativity with which various Jewish and Christian authors opined on the creation of the soul; and various interpretations of 1 Cor 15 and the

${ }^{2}$ Dem. 6.15-17 (Parisot, Aphraatis, I.297.8-I.305.21).

${ }^{93}$ Dem. 8.25 (Parisot, Aphraatis, I.405.16-20). 
subsequent implications for beliefs about the resurrection appear in the surviving literature of a number of Christian communities, covering virtually the entire range of expressions of earliest Christianity. However, none of these prior traditions "explains" or "contextualizes" Aphrahat's views in isolation from the others. Yet if we consider the composite picture of these traditions, it is possible to view Aphrahat's writings as the attempt to provide some sense of stability, a concrete expression of belief and practice emerging out of the inchoate, unorganized state of Christian identity in fourthcentury Persia. The writings attributed to Aphrahat are thus not a representative of "Christianity" over and against other religious communities; rather, they are a witness to a stage in the development of Christian identity in Persia when the precise contours of Christian practice and belief were not well defined.

\section{$* * *$}

As a postscript, it is worth reflecting on whether or not Aphrahat's attempt to define a particular Christian identity was successful. Although we do not have much direct data for the immediate reception of the Demonstrations, it is noteworthy that the first known Syriac author who explicitly engages content from the Demonstrations, George, bishop of the Arabs, was not impressed with the writings of the anonymous Persian Sage. ${ }^{94}$ Writing to his pupil, Yeshu', George argues that the Persian Sage should not be counted among the

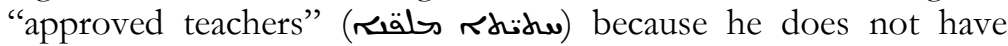

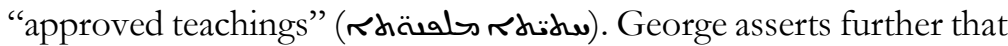
the Demonstrations contain many "errors" (Кina) and dissuades Yeshu' from reading them further. ${ }^{95}$ Somewhat ironically, it is precisely Aphrahat's discussion of the indwelling of the Holy Spirit, touched upon in the argument above, that George finds most objectionable. This brief episode from the reception history of the Demonstrations provides further evidence that the writings of Aphrahat witness to a developmental phase in Syriac-speaking Christianity, and Aphrahat's expression of Christian identity was by no means authoritative.

94 George does not know the identity of the author of the Demonstrations, whom he refers to only as the Persian Sage; George, Bishop of the Arabs, "Letter 4." As a text and translation, I have used Jack Tannous' unpublished edition of George's letters.

95 George, Bishop of the Arabs, "Letter 4." 
